DOI: https://doi.org/10.15407/rej2018.02.004

UDC 621.039.05

PACS: 33.80-b

\author{
N. N. Chernyshov, A. V. Belousov, M. A. F. Alkhawaldeh", V. M. Pisarenko*, I. V. Rogozin \\ The Federal State Budget Educational Institution of Higher Education \\ "Belgorod State Technological University named after V. G. Shukhov". \\ 46, Kostyukova street, Belgorod, 308012, Russian Federation \\ "Kharkov National University of Radio Electronics \\ 14, prospect of Science, Kharkov, 61166, Ukraine \\ E-mail: mykola.chernyshov@nure.ua
}

\title{
PHOTOVOLTAIC EFFECT AT SPIN RESONANCE IN QUANTUM MAGNETIC FIELD
}

\begin{abstract}
Subject and purpose. The article is devoted to the investigation of the photovoltaic effect in n-InSb under optical transitions between the spin subbands of the Landau levels for the ultraquantum limit. The geometry is considered when the polarization is perpendicular, and the current is directed along the magnetic field. The effect is due to the cubic terms in the Hamiltonian that exist due to the absence of an inversion center. The dependence of the current on the magnetic field has a resonance character. Such an effect is associated with resonance in the intermediate state and interference of the second-order transition amplitudes with respect to relativistic contributions to the Hamiltonian. The aim of the work is a theoretical and experimental study of the photovoltaic effect for spin resonance.

Methods and methodology. The photovoltaic effect in optical transitions between the spin-subzones of the Landau levels is considered in the article. The geometry of the system under investigation is as follows: the polarization of the electric field is perpendicular, and the current is directed along the lines of force of the magnetic field. Calculation of the magnetic field components and current density was carried out using the finite element method, which is implemented in the ANSYS software. The dependence of the current density on the magnetic field strength is analyzed. This dependence has a resonance character and contains field contributions with even and odd numbers. This effect is associated with resonance in the intermediate state and interference of the amplitudes of relativistic second-order contributions to the Hamiltonian.

Results. The practical value and scientific novelty lie in the study of the photovoltaic effect at spin resonance. Since a weakly absorbing medium is considered, an increase in the photovoltaic effect is observed as a result of the divergence of the mean square electric field modulus. The practical significance of the results lies in the development of a methodology for studying band parameters, and the terms in the Hamiltonian can lead to electrodipole transitions and photocurrents.

Conclusions. The results of the photovoltaic effect study supplement the experimental measurements of light absorption in a weakly absorbing medium. The same components in the Hamiltonian can lead to electric dipole transitions. Fig 1. Ref.: 5 items.
\end{abstract}

Key words: photovoltaic effect, Landau levels spin, wave vector, crystal inversion, asymmetric probability, circular polarization, electrodipole transitions.

The phenomenon of combined resonance (light absorption at the expense of the electric component of a electromagnetic wave, which is caused by election transitions with a spin-flip) still continues being in a sphere solid state physics shows interest. For the interference phenomenon of magnet and electrode-pole resonances in the Foygt configuration in crystals without an inversion centre. Investigating photovoltaic effect (PVE) is of special interest. Both light absorption and PVE are calculated by the absence of the medium central symmetry. The aim of the work is theoretical and experimental investigation of photovoltaic effect in spin resonance. Practical value consists in development of methods for the investigation of conditioning parameters, because the terms in the
Hamiltonian can lead to electric-dipole transitions and the photocurrent.

1. Light polarization. Let us consider a current along the direction of a magnetic field $\vec{H}$ in propaganding light along the same direction (Faraday geometry). The light polarization and orientation $\vec{H}$ with respect to crystallographic axes are considered to be arbitrary. Suppose, the conditions are met which comply with the super quantum limit: $\omega_{s}=|g| \mu_{B} \vec{H}>>$. Is the energy of a spin transition, $\vec{E}_{F}$ is the Ferni level counted from the bottom spin sub band, $\mu_{B}$ is a Bohr magneton, g is a factor, $\vec{A}$ are vector potentials of a static uniform magnetic field and a electromagnetic wave [1] 


$$
U(\vec{r})=\sum_{i} u\left(\vec{r}-\vec{r}_{i}\right)
$$

is the potential energy of interaction of elections with chaotically distributed impurities $\left(\vec{r}_{i}\right.$ is a coordinate of the i-th impurity centre). The Hamiltonian of the system considered takes the form $H=H_{0}+H_{1}+H_{2}+H_{U}+U+F$, where $H_{0}$ is a Hamiltonian of a free election in parabolic approximation. The summands $H_{1}, H_{2}$, $H_{U}$ correspond to three possible mechanisms of a transition with a spin-flip. The terms of Hamiltonian $F$ calculate the interaction of elections. The existence of a current along the direction of the field $\vec{H}$ requires the address of transition probability as a function of a longitudinal momentum $P_{z}$. As we are interested in election transitions, within the Landau level at $n$, we will omit this index in all the quantities. The part of the distribution function, potentially odd in impulse, contributing to the current, can emerge as a result of the oddness of a generation function. On the first order of perturbation theory the asymmetric part of a transition probability can appear at the expense of the interference of the contributions $F_{1}$ and $F_{2}$. The terms have been analyzed that emerge due to the address of scattering probability on impurities in $\vec{p}$. At has been found that in the super quantum limit (unlike the case of absence $\vec{H}$ ). These terms don't result in PVE. The oddness of the generation function is not either available in the parabolic approximation for an election spectrum. With view of the spectrum nonparabolicity the contribution to the current has been found [2;3]

$$
\begin{aligned}
& \vec{j}_{z}^{(1)}=\frac{\vec{e}^{3} \delta_{0} \tilde{g} \omega_{s}^{2} \vec{E}_{0}^{2} m}{\pi a^{4}|g| \varepsilon_{g} \omega^{2}} \times \\
& \times \int d p_{z} f_{p}^{(0)}+\frac{\partial}{\partial m}\left(\tau_{p}+v_{p}^{2}\right) \times \\
& \times \vec{p}_{z}\left(a^{2} \vec{p}_{z}^{2}-\frac{1}{2}\right) P \delta_{\eta}(\Delta) .
\end{aligned}
$$

Here $P$ is a delta-function, blurred on the broadening $n, \Delta$ is fuming out of resonance.

2. Asymmetric probability. In addition to the considered input to the current, there are more components associated with inputs in asymmetric probability of a transition with spin flip from the interaction of electrons with impurities. It may seem that transitions with spin flip, with the participation of impurities are not resonant, as it does not maintain $\vec{p}$. However, PVE in this case is determined by the resonance in the intermediate state. The reason for this is similar to the reason of occurrence of resonance PVE in the quantum film. These inputs arise when considering the interference of transition amplitudes of first and second order. For the case $(\Delta<<\lambda)$ of input received in the form

$$
\begin{aligned}
& \vec{j}_{Z}^{(2)}+\vec{j}_{Z}^{(3)}=-\frac{4 \pi \alpha_{S} \vec{e}^{3} \vec{n}\langle\lambda\rangle}{a^{2} \omega^{2}} \times \\
& \times \vec{E}_{0}^{2}\left\{\delta_{\eta}(\Delta)-\frac{\tilde{g} \omega_{S}}{\alpha_{S}|g|} \dot{\delta}_{\eta}(\Delta)\right\} \dot{P} .
\end{aligned}
$$

In [4] was measured PVE and the effect of an increase of the spin transitions in InSb with $\vec{H} /[111]$. Analysis of experimental results showed that the measured signals do not depend on the angle between the vector of linear polarization and crystallographic directions in the (111) plane. Therefore, for the experimental curves obtained in opposite directions of the wave vector of light $\vec{q}$ photovoltaic component of the signal, independent of the sign of the wave vector $\vec{k}$ of the radiation, build a symmetrical combination of signals in opposite directions of light propagation $U$. In the figure bellow shows the dependence of the PVE signals from $\vec{H}$ for linear, and right and left relative to the direction $\vec{H}$ of the circulating polarizations.

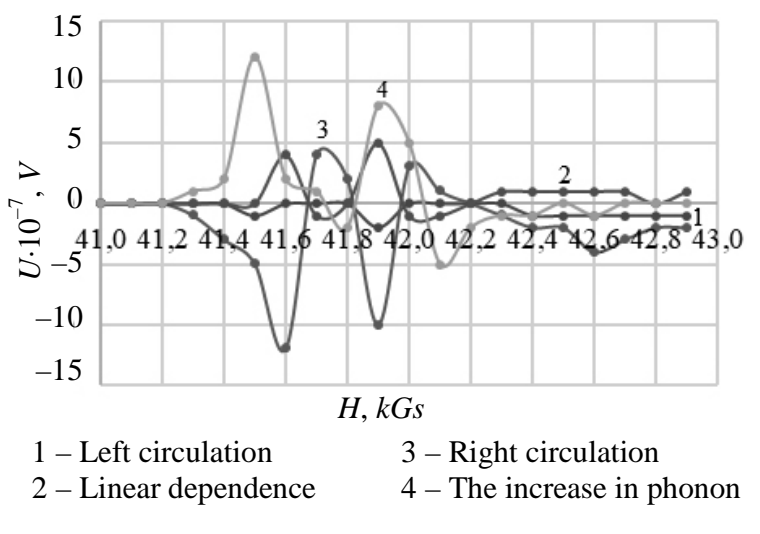

Dependence of EMF PVE from $\vec{H} /[111]$

The figure shows that the effect exists only for linear and right-circular polarizations. The amplitude of the signal for circular polarization in two times more than linear one. The change of sign of $\vec{H}$ does not affect the value effect in the 
linear polarization of the radiation. The signal contains both an even and odd inputs of configuration of the resonance. From the table it is seen that in this orientation only appear $\vec{j}_{z}^{(2 ; 3)}$. From a comparison of theoretical values with the experimental signal we will get $\alpha_{S}=5.7 \times 10^{14} \mathrm{~cm}^{2}$, which agrees well with the value of the parameter, obtained from the even input in the orientation $\vec{H} /[111]$. For the odd input, we will receive a value of the signal $4.7 \times 10^{-4} \mathrm{~B}$, which exceeds the experimental value $4.2 \times 10^{-7} \mathrm{~B}$. Theory of the effect is well described, highlighting the observed polarization dependence in the considered orientations of $\vec{H}$ relative to the crystallographic directions [5]. Comparison of theoretical and experimental values of the signals for the even configuration from the resonance the input allows you to define the parameters $\tilde{g} ; \alpha_{S}$. The values of these parameters are in good agreement with their values, calculated in Kane model. Theoretical value the odd input by $\Delta$ input is by almost three orders higher than experimentally observed expected value. This is partly due to the fact that the heterogeneity of $\vec{H}$ in the volume occupied by the sample, leads to the suppression of the alternating signal and has little effect on the value of constant value of the input. Inputs not taken into account by the theory describing the odd $\Delta$ peak are possible. Impurity peaks behave as peak spin resonance by free carriers. Between bound states only internal transitions are allowed. In such transitions of free electrons appear due to the auto-ionization processes. The input of the states in the PVE stems from the fact that the excited impurity states are intermediate and the final state is free.

3. Strengthening of the PVE in 2D-disordered medium. Let's consider the distribution of $\vec{E}$ in a weakly absorbing environment. In randomly inhomogeneous macroscopic mediums constructed of non-absorbent microscopic parts, due to the excitation of local plasmons occurs the enhancement of the local electric fields. In this mediums from the average values of the even powers of a module $\vec{E}$ differ and are crucial for different nonlinear responses of the system, which leads to their strengthening. A two-phase medium consisting of two statistically mixed components $\varepsilon_{1} ; \varepsilon_{2}$ possesses an effective dielectric transmissivity $\varepsilon_{\text {eff }}=\sqrt{\varepsilon_{1} \varepsilon_{2}}$. If both media are metals described by the Drude-Lorentz model

$\varepsilon_{1,2}=1-\omega_{P(1,2)}^{2} / \omega\left(\omega+\frac{i}{\tau_{1,2}}\right)$,

and absorption in them is very small $\tau \rightarrow \infty$. Then the initial media do not have absorption. If frequency of light $\omega$ lies between the plasma frequencies $\omega_{P}$ in the medium there is a finite absorption. The mean values of the square of the complex $\vec{E}$ and the square of the modulus of the

$\left\langle|E|^{2}\right\rangle=\frac{\left(1+\left|\varepsilon_{2} / \varepsilon_{1}\right|\right)}{\sigma_{1}\left|\varepsilon_{2} / \varepsilon_{1}\right|+\sigma_{2}}|\langle\vec{E}\rangle|^{2}$.

The value $\left\langle|E|^{2}\right\rangle$ differs, but $\left\langle\vec{E}^{2}\right\rangle$ remains bounded with increasing relaxation time. The model uses two iteration stages, one of the environments is replaced by empty gaps. As a result, a chain of conductivities arises $\sigma_{1 ; 2}^{n}$. An endless repetition of the procedure leads to the same values $\sigma_{1 ; 2}^{\infty}$, which coincides with the Dykhne relations $\sigma_{\text {eff }}=\sqrt{\sigma_{1} \sigma_{2}}$. For the case of direct current $\varepsilon_{1 ; 2}$ as an imaginary value, and the resulting chain converges to the result of Dykhne. The same is true for real positive $\varepsilon_{1 ; 2}$, corresponding to the static $\varepsilon$. By analogy with [5], display (3) should lead to the scenario of dynamic chaos for purely real $\varepsilon_{1 ; 2}$ with opposite signs. The result is sensitive to the initial value, and at any step isotropy of the system is not observed: $\varepsilon_{1}^{n} \neq \varepsilon_{2}^{n}$. Thus, the problem reduces to a nonlinear recurrence relation for the dielectric transmittivities.

Conclusion. The article is devoted to the study of PVE in optical transitions between spin sub bands of the Landau levels. Considered geometry, when the polarization is perpendicular, and the current is directed along $\vec{H}$. The dependence of $\vec{I}$ from $\vec{H}$ is of resoance character, and contains both even-numbered and oddnumbered field inputs. This character of effects is associated with resonance in an intermediate 
state and the interference of transition amplitudes of the second-order relativistic inputs to the Hamiltonian function. Practical value and scientific novelty is concluded in the study of PVE at spin resonance. It can complement experiments on light absorption measurement as a method of conditioning parameters, as the same components in the Hamiltonian function can lead to an electric dipole transitions. The article examines PVE in weakly absorbing medium. It is shown that as a result of the divergence of the average square modulus of $\vec{E}$ there is an increase in effective PVE.

\section{REFERENCES}

1. Brouers, F., Henrioulle, N., Sarychev, A., 1996. In: Electrical Transport and Optical Properties of inhomogeneous media. Moscow: Scientific Center for Applyed Problems in Electrodynamics, p. 46.

2. Kraut, W., Baltz, R., 1979. Anomalous bulk photovoltaic effect in ferroelectrics: a quadratic response theory. Phys. Rev. B, 19(3), pp. 1548-1554. DOI: https://doi.org/ 10.1103/PhysRevB.19.1548

3. Baltz, R., Kraut, V., 1978. A model calculation to explain the existence of bulk photo-current in ferroelectrics. Solid State Commun., 26(12), pp. 961-963. DOI: https://doi.org/10.1016/0038-1098(78)91262-0

4. Chernyshov, N. N., Slusarenko, A. A., 2016. Study the photovoltaic effect in the spin resonance for crystals without inversion centre. In: Zbior artykulow naukowych / Inzynieria i technologia. Nauka wczoraj, dzis, jutro. Warszawa, Poland, 02.2016, pp. 53-58.

5. Chernyshov, N. N., 2015. Conductivity of multicomponent electron gas. Radioelectronics \& informatics, 1(68), p. 23-25.

Рукопись поступила 29.03.2018.

Н. Н. Чернышов, А. В. Белоусов, М. А. Ф. Алкхавалдех, В. М. Писаренко, И. В. Рогозин

\section{ФОТОГАЛЬВАНИЧЕСКИЙ ЭФФЕКТ ПРИ СПИНОВОМ РЕЗОНАНСЕ В КВАНТОВОМ МАГНИТНОМ ПОЛЕ}

Предмет и цель работы. Статья посвящена исследованию фотогальванического эффекта в $n$-InSb при оптических переходах между спиновыми подзонами уровней Ландау для ультра квантового предела. Рассмотрена геометрия, когда поляризация перпендикулярна, а ток направлен вдоль магнитного поля. Эффект обусловлен кубическими членами в гамильтониане, существующими из-за отсутствия центра инверсии. Зависимость тока от магнитного поля имеет резонансный характер. Такой характер эффекта связан с резо- нансом в промежуточном состоянии и интерференцией амплитуд перехода второго порядка по релятивистским вкладам в гамильтониане. Целью работы является теоретическое и экспериментальное исследование фотогальванического эффекта при спиновом резонансе.

Методы и методология работы. В статье рассматривается фотогальванический эффект в оптических переходах между спиновыми подзонами уровней Ландау. Геометрия исследуемой системы следующая: поляризация электрического поля перпендикулярна, а ток направлен вдоль силовых линий магнитного поля. Расчет компонент магнитного поля и плотности тока проводился с использованием метода конечных элементов, который реализован в ПО ANSYS. Проанализирована зависимость плотности тока от напряженности магнитного поля. Эта зависимость имеет резонансный характер и содержит полевые вклады с четными и нечетными номерами. Этот эффект связан с резонансом в промежуточном состоянии и интерференцией амплитуд релятивистских вкладов второго порядка к гамильтониану.

Результаты работы. Практическая ценность и научная новизна заключаются в исследовании фотогальванического эффекта при спиновом резонансе. Поскольку рассматривается слабо поглощающая среда, наблюдается увеличение фотогальванического эффекта в результате расходимости среднего квадратичного модуля электрического поля. Практическое значение результатов заключается в разработке методики исследования зонных параметров, а слагаемые в гамильтониане могут приводить к электродипольным переходам и фототоку.

Заключение. Полученные результаты исследования фотогальванического эффекта дополняют экспериментальные измерения поглощения света в слабо поглощающей среде. Одни и те же компоненты в гамильтониане могут приводить к электрическим дипольным переходам.

Ключевые слова: фотогальванический эффект, спиновые уровни Ландау, волновой вектор, инверсия кристалла, асимметричная вероятность, циркуляционная поляризация, электродипольные переходы.

М. М. Чернишов, А. В. Бєлоусов, М. А. Ф. Алкхавалдех, В. М. Писаренко, I. В. Рогозін

\section{ФОТОГАЛЬВАНІЧНИЙ ЕФЕКТ ПРИ СПІНОВОМУ РЕЗОНАНСІ У КВАНТОВОМУ МАГНІТНОМУ ПОЛІ}

Предмет і мета роботи. Статтю присвячено дослідженню фотогальванічного ефекту в $n$-InSb при оптичних переходах між спіновими підзонами рівнів Ландау для ультраквантової межі. Розглянуто геометрію, коли поляризація перпендикулярна, а струм напрямлений уздовж магнітного поля. Ефект обумовлений кубічними членами в гамільтоніані, існуючими через відсутність центру інверсії. Залежність струму від магнітного поля має резонансний характер. Такий характер ефекту пов'язаний з резонансом у проміжному стані та інтер- 
ференцією амплітуд переходу другого порядку за релятивістськими внесками в гамільтоніані. Метою роботи $\epsilon$ теоретичне та експериментальне дослідження фотогальванічного ефекту в умовах спінового резонансу.

Методи і методологія роботи. У статті розглядається фотогальванічний ефект в оптичних переходах між спіновими підзонами рівнів Ландау. Геометрія досліджуваної системи така: поляризація електричного поля перпендикулярна, а струм спрямований уздовж силових ліній магнітного поля. Розрахунок компонент магнітного поля і густини струму проводився з використанням методу скінченних елементів, який реалізований з використанням П3 ANSYS. Проаналізовано залежність густини струму від напруженості магнітного поля. Ця залежність має резонансний характер і містить польові внески 3 парними і непарними номерами. Цей ефект пов'язаний з резонансом у проміжному стані та інтерференцією амплітуд релятивістських внесків другого порядку до гамільтоніана.
Результати роботи. Практична цінність і наукова новизна полягають в дослідженні фотогальванічного ефекту в умовах спінового резонансу. Оскільки розглядається слабо поглинаюче середовище, спостерігається збільшення фотогальванічного ефекту в результаті розходження середнього квадратичного модуля електричного поля. Практичне значення результатів полягає в розробці методики дослідження зонних параметрів, а складові в гамільтоніані можуть призводити до електродипольних переходів і фотоструму.

Висновок. Отримані результати дослідження фотогальванічного ефекту доповнюють експериментальні вимірювання поглинання світла в слабо поглинаючому середовищі. Одні й ті самі компоненти в гамільтоніані можуть призводити до електричних дипольних переходів.

Ключові слова: фотогальванічний ефект, спінові рівні Ландау, хвильовий вектор, інверсія кристала, асиметрична ймовірність, циркуляційна поляризація, електродипольний перехід. 